\title{
Cystine Measurement
}

National Cancer Institute

\section{Source}

National Cancer Institute. Cystine Measurement. NCI Thesaurus. Code C105441.

The determination of the amount of cystine present in a sample. 